\title{
Ludic Scopes for Environmental Crisis and Education
}

\author{
Giorgio Osti
}

\begin{abstract}
The article aims to add a ludic perspective to those generally used for studying environmental issues in social sciences. To introduce in the debate a play/game metaphor enriches the interpretations of environmental crisis and provides a further motivation to action. The ludic perspective has a sociorelational background. That tradition of studies helps in constructing a set of categories that are then applied to environmental education (EE). The choice of such a topic is motivated by two factors: EE is an aspect generally practiced but mistreated in the main theorizations, and EE is exemplary of the potentialities of the playing games metaphor, which are the desire to create, the acceptance of slow changes, the protection of an experimental bubble, and irony toward environmental issues.
\end{abstract}

Keywords: environmental education, games, motivations, playing, relationships

"Sur le rivage de mondes sans fin, des enfants . . jouent." —Rabîndranâth Tagore, La Jeune Lune

\section{Introduction}

"Given environmental change is as much about production, institutions, inequality and power" (Lockie 2015: 2), the article aims to add a further perspective, less "hard" than that quoted, and more joyful. Of course, power and inequalities explain much of environmental issues. But they neglect ludic dimensions of human interactions. To introduce in the debate a play/game metaphor could enrich the interpretations of environmental crisis and provide a further motivation to action. The ludic perspective has a sociorelational background, specified with an anthropological approach to games. That tradition of studies helps in constructing a set of categories that are then applied to environmental education (EE). The choice of such a topic is motivated by two factors: $\mathrm{EE}$ is an aspect generally practiced but mistreated in the main theorizations, and EE is exemplary of the heuristics of the playing games 
metaphor. In the end, some potentialities of EE games are illustrated: the desire for knowing and creating (arts), the acceptance of slow changes (gradualism), the protection of an experimental space (bubble), and irony toward environmental issues.

\section{Game Playing, the Addendum to Environmental Crisis Interpretations}

The game/play perspective has a wide range of meanings. Three fields of research seem prominent: (1) studies of a historical and anthropological nature, of which John Huizinga (2002) is the progenitor; (2) research on recent massive social phenomena, with gamification as the macro example (Bittanti and Zilio 2016); and (3) the use of game as a metaphor for the entire functioning of society - that is, "every institution partially works as a game" (Callois 1981: 83). The latter field is favored in this article and will be used in an attempt to create a framework for interpreting environmental issues.

The multidimensional and overlapping nature of game/play offers a formidable metaphor for what humans do with environmental goods and ecosystems. Generally, people contemplate/take care of the environment or they transform it for instrumental reasons. However, there are further motivations, among which is playing with the environment to achieve pleasure for oneself and others. Thus, the primary scope is not protection of the environment, but support for improving intrahuman relationships.

The aim is to develop a model of environmental actions that is plural: it should consider the classical stewardship and instrumental motivations, but add specific drivers coming from the pleasure of playing. This idea is not new. Environmental NGOs have discovered the great potential of gamification, creating mild competitions among young people for recycling waste (Szaky 2016). Psychologists of the nudge approach have demonstrated that making a dweller aware of the better performances of neighbors pushes that neighbor to improve his or her own energy use (Cialdini 2007).

This evidence shows that game is deeply rooted in the human condition, almost an ontological dimension. It can offer not only a means for people's involvement in a cause, but also interpretative keys for their behaviors. The approach is thus to develop the metaphorical or representative potential of game/play theory. We start with some advantages game can provide to social sciences theorization. 
The first is the already mentioned distinction between game and play that Roger Callois ([1967] 1981) formulated, respectively, with ludus and paidia. Usually, the former indicates a set of rules, the latter the practice, the effective execution of the game. The fusion between the two terms comes from the idea that rules are not simply followed, but interpreted and partially modified during each game. "We can understand these actions as moves in a game, of which the rules somewhat alter while the game is being played" (Geels 2004: 908).

Situational factors and relational contingency intervene in compliance with game rules. Thus, game playing helps to overcome a typical actor-structure dilemma, as indicated by Bourdieu: the best example of disposition is undoubtedly the sense of game (2009: 163).

Another advantage of game metaphor is the capacity to keep a variety of types under the same umbrella. Scholars agree that it is better to speak of games in the plural (Rovatti 2017). Callois ([1967] 1981) identified four types of game: agon, alea, mimicry, and ilinx (competition, randomness, imitation, vertigo). This delineates a conceptual improvement in social analysis, always searching for ways to conjugate differentiation and unity in society.

Play has "primacy over the consciousness of the player" (Gadamer 1992: 104). This is a famous statement that can be interpreted in opposing ways: to mortify actors' subjectivity or with a proper consideration for the dynamics of society, a so-called emergent quality that justifies sociology. Nevertheless, Hans-Georg Gadamer's insistence on playing as an over-individual context does not simply affirm games' rule constraints.

According to Carlo Mongardini (1998), game is an institution (or a fixed representation of society); in addition, there is the capacity to play with the rules - that is, the ability to interpret and manipulate the rules, like a lawyer or an orator. Finally, there is the third level-the game of sociability (Geselligkeit) that is played outside society. This is Georg Simmel's term (1984), indicating "soft" relationships into which the personality and social rank of the actor do not enter (Ereck 2014: 51).

Thus, the game metaphor represents very well the actor-structure continuum, going from a supersocialized individual to those able to abstract themselves from any role or identity. Game as the ability to distance oneself from an assigned role is an idea also expressed by Erving Goffman (1961) and Eugene Fink (2008). It is a further way to overcome the mentioned dichotomy between actors' freedom and structure conditioning: the subject, limited by rules and nature, constantly searches for new combinations or game schemes. 
Besides conceptual advantages, there are some heuristics of game: seriality and the blurring of borders. Seriality is motivated by the fact that nobody is able to take complete control of the situation. The game remains in a sense "always open"; thus, indeterminacy moves to a further game in an endless relationship (Carse 1987). James Carse adds that it is difficult to close a game because it is based on reciprocity, the desire to maintain a relationship with others, a concept close to the meaning of a modern gift (Godbout 1998).

Martino Doni and Stefano Tomelleri (2011) place repetition in the grammar of game as an invariant and basic feature. However, the meaning they ascribe it is ambivalent. First, there is pleasure in repetition: children and older people generally like catchphrases. However, the benefit of game repetition also risks being a mask in Freud's sense: the obsessive repetition of an action hides neurosis, almost an impulse to death (Deleuze 1976). This interpretation moves toward pathologies like compulsive gambling disorder, a universe of hurt and addiction that shows the dark side of game and gamification. Nevertheless, repetition can assume a radically different meaning: reversibility, sequence, seriality - that is, an ordered replication of the scheme but not of the result. Game works in a double sense: as a legal guarantee for the weak and as a real chance to reverse the results. Therefore, repeating the game gives insurance for those who are not the favorites, reducing violent conflicts.

A further heuristic of the game metaphor is that of blurring the border between reality and fiction. We usually confine game to the sphere of the ludic, noninstrumental, imaginative, relaxing. It is a sphere completely detached from real life. When playing or watching a game, people are in a bubble. Scholars say the situation is more complex, however, because the border is osmotic. According to Fink (2008), games were magic in origin and represented the foundation of society. More than clans or power celebrations, games united the community in explosive festivals. Games have been successively secularized, becoming something more similar to a relaxing bubble. However, the original meaning is not fully lost: the Olympic Games are probably nowadays the last common celebration of world community. Games, then, represent a moment of foundation, ludic activities legitimating the serious ones.

A second factor of connection is the interdependency between real and game moments. The latter function to keep order in the former. People need panem and circenses to keep them subjugated or ready to give support to a leader or political faction (clients). The modern version of "bread and circuses" has several variants, like gamification (Bittanti and Zilio 2016). 
A third point of conjunction is space, the physical space in which both ludic and real activities happen. Again, Fink (2008) raises this matter. Such spaces can be contiguous - think of the workplace gym, for example-and allow players to compare themselves with others and show their different abilities (De Conciliis 2017: 83). But there is a deeper relationship with space. We have codified game as always present in human relationships, as in Goffman's (1961) distance from an assigned role, the ironic interpretation of a task-in general, a capacity to play with others' expectations. This joyful dramatization requires not only scenery and a setting but also the actor's ability to play with space forms, like distance, altitude, channels, holes.

We can stylize the interconnections between fictiveness and serious activities in the following ways:

(1) All real situations are a fiction. During a funeral, not all the people feel pity for the dead, but they cry or show grief. It is the triumph of hypocrisy, the ideal typical situation considered by Goffman (1956) in his theory of dramaturgy.

(2) In any situation, moments of fiction and moments of realism alternate. On a battlefield, the commander moves troops for real or sham attacks. These are the strategic behaviors thought by Michael Crozier and Erhard Friedberg (1977) to describe life within industrial organizations.

There is a third situation in which game and seriousness are so intertwined that it is difficult to keep the conceptual distinction. The extreme ability and ambiguity of actors, coupled with difficulties in the perception of the environment, produce such situations. The world of spies and secret services is an example. The double cross (doppio gioco) is pertinent here, as well as an element of self-cheating, where people play with their own lives without full awareness of what they are doing. Not by chance, Simmel ([1908] 2009) assimilates game with other strange activities like adventure and traveling.

\section{The Environmental Game Framework}

We have arrived at a point in dealing with the game/play perspective where a translation to environmental issues is possible. The focus is on the bundle of intrahuman relationships in which playing games is relevant. To look at games means to consider human-environment 
relationships in new ways, adding to traditional instrumental-symbolic meanings a relational dimension that is usually lacking in environmental sociology.

The framework, already experimented with in relation to energy (Osti 2018), can be divided into game conditions and qualities. The former are necessary elements for envisaging an environmental game; the latter are specific features that are present in a big way, allowing us to elaborate a research hypothesis. The conditions are:

(1) An environmental issue broadly framed as game (competition, race, performance, trial, context, talent show).

(2) Socially recognized players: NGOs, environmental agencies, eco-entrepreneurs. Competitors can be alone against an impersonal body like an ecosystem.

(3) A playground - a physical place where the game happens. Generally, for environmental causes, this is a public place like a tribunal or meeting room, or a square. Virtual games are excluded.

(4) A referee or arbiter. This is not simply about observing the game rules, but having a person or a team ready to interpret those rules in situ.

Game qualities are:

(1) Publicity, in two senses: an environmental game is stronger if there are many spectators (public), and a game is more representative when rules and conditions are known (transparency).

(2) Tokens: a game is more attractive when the tools for playing-toys, in Fink's (2008) language-are important symbols for the society. Charismatic species or megafauna are a good example in the environmental field (Ducarme et al. 2013).

(3) The chance to repeat the game. Repeating the game provides many opportunities, not least developing cooperation among players, which is codified in classic game theory (see Axelrod 2006). Repetition promotes abilities and usually protects the weaker player. Finally, it has a special meaning for environmental goods, whose problem is irreversible degradation. The idea of repeating the game imposes conservation of the environment that is an integral part of the competition.

(4) Game-seriousness swing. It is difficult to codify this dimension. Evidently, relationships in which seriousness alternates with jocular moments are more mature and productive, because of the flex- 
ibility of the actors, a shared sense of humor, and an awareness of each other's limits. How to capture such a dimension rests on participant observation and ethnographic methods.

\section{Games for Environmental Education}

Environmental education (EE) is a good test for game/play theory because it is considered an amusing and involving ecological activity. It is often considered a secondary activity (Palmer 1998: i) compared to environmental politics, but organizations usually do some sort of environmental education. A quick search on the issue of water shows how educational activities are flourishing in a variety of organizations: utilities, NGOs, schools, companies. EE evidently has an ancillary function.

It is interesting, then, to ascertain whether the game/play perspective adds some insights to the pedagogy of ecological crisis. In general, EE programs mention games as a technique for improving the learning process and satisfying the authentic needs of children (they rarely cater to young people or adults). A second general aspect is the competitive formula. Individuals and, more often, groups and school classes are invited to complete a quiz or write an essay on an environmental issue, the prize for which can be money, a cultural trip, or educational tools. Prizes are delivered publicly in the presence of authorities.

This is the usual phenomenology. Game metaphor, however, aims to penetrate the intimate structure of EE to find some heuristics. Many disciplines deal with the subject of game and education. In the Marxistinspired urban sociology, reference to game is ambivalent: on the one hand, gamification is seen as the quintessential control of minds and expropriation of value; on the other, it is a source of liberation and sense making: "One can say that there will be play between the parts of the social whole (plasticity) — to the extent that play is proclaimed as supreme value, eminently solemn, if not serious, overtaking use and exchange by gathering them together" (Lefebvre 1996: 172). Henri Lefebvre also mentions the arts and philosophy as tools for organizing urban games, seen as oeuvre. According to Huizinga (2002), poetry and music are strictly linked to games because of their capacity to represent, respectively, myths and useless activities. Desire to know (epistemophilia) is frequently mentioned in attitudes toward nature (Fellin 2018). Both appear to be fundamental tools of EE. However, both remain ambivalent, because the desire to represent or know nature is a typical individual activity (New 2015; Sciachittano 2017). 
In contrast, games most often are relational. The self has to face the other-often, others or the generalized other. Egocentric perspectives and positions are then tempered. Games' temperance allows the introduction of another possible heuristic for EE. A measured use of games in EE can promote gradualism, incremental change to overcome Manichean or dialectical positions on environmental issues.

Gradualism, seen by John Urry (2010) as one of three main discourses on climate change, is typical of every educational activity that advances by steps, loops, and evaluations. Game playing has the same structure, especially when repeated. Gradualism (or reformism, in political terms) does not cogently represent how nature or society change, but it has the capacity to create a pattern. If adopted, it becomes a good exercise-an ascetic - in EE.

Davide Zoletto (2017), following Jan Masschelein and Maarten Simons (2013), develops the metaphoric capacity of game, considering school as a vacuum, an empty space where students can play without the constraints of their social origin or personality. This recalls Simmel's wonderful concept of sociability applied to the school context. Real inclusion - think, for example, of sons of migrants - is not to promote differences but to allow a free and protected stream of experiences. This is playing a game. With some rules to follow, it means experimenting with a world partially closed to the external "sharp" rules of competition and discrimination.

The game metaphor can be applied to different school disciplines: some are important and easily evaluated, such as mathematics, and they tend to reproduce social and cognitive unbalances; others, such as the arts, religion, and physical education, can be better viewed as a vacuum in which to experience creativity and deliberation. EE can be the same. However, the parallel is more intriguing. The real stake, like in a game, is not to give students maximum freedom as they go wild in the classroom, but to foster a new intermediation with the external world. It is again the swing of realism and fantasy during human game playing (Winnicott 1975; Monnier 2012).

If we consider the environmental crisis a new phenomenon without a specific discipline for studying it, then EE can cover that space. It is not physical sciences, nor economy nor geography. We can reverse the idea of school as a free space protected from external inequalities and discriminations, imagining the relationship with the (external) environment as an experience of freedom. Pupils playing in a green space experiment with the same freedom and inclusiveness they have with "minor" disciplines within the classroom. Thus, not only does playing 
at school increase sociability, but so too does playing in open green spaces. EE is in a strong position to provide this experience.

A further possible parallel between game/play and EE concerns humor. Game, in its sense of leisure and recreational activity, has many connections with humor and making others amused. Callois's four game meanings probably neglected the ridiculous side of playing together: game is too much charged with tremendous serious meanings. Indeed, playing is also not taking reality too seriously, showing weaknesses, funny aspects, and clumsiness.

In any case, humor can be an important educational strategy, even for environmental issues, which are generally seen in a very dramatic way. According to Boris Cyrulnik (2009), humor can promote "personal" resilience. Here, "environmental" resilience can be added-that is, the capacity of a residential community to re-create a satisfying balance with the material world after a perturbation. Patrizia Garista (2018: 112) says "more bodily and physiological aspects of resilience highlight some specifically educational veins that recall the materiality of education" (my translation). EE is not a pure cognitive flow, but a transformative force of both an internal and an external nature (bodies and environments).

Humor, being a force able to show the unexpected funny sides of humans, opens new ways to understand and transform reality and thus learning capacity. Noteworthy is the limited irony developed toward environmental militancy or lifestyles: it is very rare to find texts of any kind in which the environmentalist is ridiculed. This shows that the issue is not mature; it has not fully entered into people's normal life, allowing us to show the funny side of ecological habits, like tics or manias. Like religion (don't mix the sacred with the profane), environmentalism is too serious and rational a practice to be mocked.

It is as rare to use humor in EE; it seems tremendously serious and boring. However, this register has been used in very dramatic situations-for example, after disasters and to support people with serious diseases (Cyrulnik 2009). The problem, as Garista (2018) says, is that humor has different registers, faces different public tastes, is used for different things. Sarcasm, for example, is a way to offend people. The line between a healthy use of humor and offense is very fine, especially in today's multicultural contexts.

Nevertheless, EE offers a wide field of experimentation for developing this aspect of games. Animals are lovable, but are often quite funny. That increases our attachment to them. To find a ridiculous side of ecosystems is more difficult, but not impossible. There is the 
expression "trick of nature" to describe ridiculous combinations in the natural world. Look, for example, at the BBC program Nature's Tricks. ${ }^{1}$ Design and innovation are inspired by the natural world. Emily Anthes investigates the scientists, architects, and engineers taking their cues from nature's ingenuity to create a better blueprint for our world. Environmental educators surely have more imagination and the great advantage of looking not only at human and nature separately, but in their intimate and frequent relations. This provides material for thousands of funny situations to be used for educational aims. Thus, the game goes on, infinitely.

Giorgio Osti studied sociology at the University of Trento (Italy). He holds a PhD in Sociology and Social Research (1991) and he has been qualified (abilitazione) as full professor of Environmental and Territorial Sociology in 2013. He teaches Sociology of Migration and Sociology of Territory at the University of Trieste. His fields of research are rural development and environmental crisis; for the former he has studied local action groups, mobility, and welfare in fragile rural areas, and for the latter he has conducted research in ecological movements, waste management, energy transition, and water governance. E-mail: Giorgio.osti@dispes.units.it

\section{Note}

1. www.bbc.com/future/columns/natures-tricks (accessed 11 August 2018).

\section{References}

Axelrod, Robert. 2006. The Evolution of Cooperation. Rev. ed. New York: Basic Books. Bittanti, Matteo, and Emanuela Zilio, eds. 2016. Oltre il gioco: Critica della ludicizzazione urbana. Milan: Unicopli.

Bourdieu, Pierre. 2009. Ragioni pratiche. Bologna: Il Mulino.

Callois, Roger. (1967) 1981. I giochi e gli uomini: La maschera e la vertigine. Milan: Bompiani.

Carse, James P. 1987. Giochi finiti e infiniti: La vita come gioco e come possibilità. Milan: Mondadori.

Cialdini, Robert B. 2007. Influence: The Psychology of Persuasion. New York: Harper Business.

Crozier, Michel, and Erhard Friedberg. 1977. L'acteur et le système: Les contraintes de I'action collective. Paris: Editions de Seuil.

Cyrulnik, Boris. 2009. Resilience: How Your Inner Strength Can Set you Free from the Past. London: Penguin. 
De Conciliis, Eleonora. 2017. "Il gioco scolastico e la vertigine dello smascheramento." Aut Aut 375: 80-100.

Deleuze, Gilles. 1976. Différence et repétition. Paris: Presses Universitaires de France.

Doni, Martino, and Stefano Tomelleri. 2011. Giochi sociologici: Conflitto, cultura, immaginazione. Milan: Cortina.

Ducarme, Frédéric, Gloria M. Luque, and Franck Courchamp. 2013. "What Are 'Charismatic Species' for Conservation Biologists?" BioSciences Master Reviews 10: 1-8.

Ereck, Jarvis J. 2014. "Green Ribband Width: The Broken Metaphors of New Social Forms, c. 1680 and c. 2013." In Social Networks in the Long Eighteenth Century: Clubs, Literary Salons, Textual Coteries, ed. Ileana Baird, 31-53. Newcastle upon Tyne, UK: Cambridge Scholars Publishing.

Fellin, Emanuela. 2018. Con-vivere sulla Terra: Educarci a cambiare idea e comportamenti per una nuova vivibilità. Bergamo: ZeroSeiUp.

Fink, Eugene. 2008. Oasi di Gioco. Milan: Cortina.

Gadamer, Hans-Georg. 1992. Truth and Method. 2nd ed. New York: Crossroad.

Garista, Patrizia. 2018. Come canne di bambù: Farsi mentori della resilienza nel lavoro educativo. Milan: Franco Angeli.

Geels, Frank W. 2004. "From Sectoral Systems of Innovation to Socio-Technical Systems. Insights about Dynamics and Change from Sociology and Institutional Theory." Research Policy 33 (6-7): 897-920.

Godbout, Jacques T. 1998. The World of the Gift. Montreal: McGill Queen's University Press.

Goffman, Erving. 1956. The Presentation of Self in Everyday Life. New York: Doubleday.

Goffman, Erving. 1961. Encounters: Two Studies in the Sociology of Interaction. Oxford, UK: Bobbs-Merrill.

Huizinga, Johan. 2002. Homo ludens. Turin: Einaudi.

Lefebvre, Henri. 1996. Writings on the Cities. Oxford, UK: Blackwell.

Lockie, Stewart. 2015. "Why Environmental Sociology?" Environmental Sociology 1 (1): 1-3. https://doi.org/10.1080/23251042.2015.1066084.

Masschelein, Jan, and Maarten Simons. 2013. In Defence of the School: A Public Issue, Education. Leuven: Culture \& Society Publishers.

Mongardini, Carlo. 1998. Saggio sul gioco. Milan: FrancoAngeli.

Monnier, Claire. 2012. "Crise écologique et éducation vers une nouvelle position éthique dans le lien entre I'homme et la nature." Revue d'éthique et de théologie morale 3 (270): 97-112.

New, Caroline. 2015. Agency, Health and Social Survival: The Ecopolitics of Rival Psychologies. London: Routledge.

Osti, Giorgio. 2018. "The Uncertain Games of Energy Transition in the Island of Sardinia (Italy)." Journal of Cleaner Production 205: 681-689. doi: 10.1016/j. jclepro.2018.08.346.

Palmer, Joy A. 1998. Environmental Education in the 21st Century: Theory, Practice, Progress and Promise. London: Routledge.

Rovatti, Pier A. 2017. "Il paradosso dell'agonismo." Aut Aut 375: 3-18.

Sciachittano, Antonello. 2017. "Bambino, vuoi giocare con me?" Aut Aut 375: 101-112.

Simmel, Georg. (1908) 2009. Sociology: Inquiries into the Construction of Social Forms. Leiden, Netherlands: Brill.

Simmel, Georg. 1984. Grundfragen der Soziologie. Berlin: Walter de Gruyter. 
Szaky, Tom. 2016. "The Positive Impact of Environmental 'Gamification." Huffington Post, 8 August. https://www.huffingtonpost.com/tom-szaky/the-positive-impactof-en_b_11386874.html?guccounter=1 (accessed 9 August 2017).

Tagore, Rabîndranâth. 1923. La jeune lune. Paris: NRF.

Urry, John. 2010. "Sociology Facing Climate Change." Sociological Research Online 15 (3). http://www.socresonline.org.uk/15/3/1.html (accessed 27 December 2018). Winnicott, Donald W. 1975. Jeu et réalité: L'espace potentiel. Paris: Gallimard. Zoletto, Davide. 2017. "La scuola come 'spazio' di gioco." Aut Aut 375: 73-79. 